\title{
Meningkatkan Kreativitas Siswa Dalam Pengolahan Limbah Menjadi Trash Fashion Melalui PjBL
}

\author{
RINI ASTUTI \\ Universitas Pendidikan Indonesia \\ *email: rinifira@gmail.com
}

Manuscript received: 21 Mei 2015 Revision accepted: 30 Juli 2015

\begin{abstract}
Penelitian ini bertujuan dalam mengembangkan pembelajaran di luar kelas berbasis proyek untuk meningkatkan kretivitas siswa dalam penanganan limbah. SMK sebagai sekolah menengah kejuruan, siswanya dituntut untuk mempunyai keterampilan yang diperlukan di industri/dunia usaha. Untuk itu maka dalam kegiatan pembelajaran harus dapat mendukung tumbuh kembangnya pribadi peserta didik yang berjiwa kewirausahaan dan mempunyai kecakapan hidup. Salah satunya melalui pembelajaran berbasis proyek dengan mengolah limbah menjadi trash fashion. Penelitian diawali dengan observasi lingkungan sekolah oleh guru, kemudian guru menyusun lembar kerja siswa (LKS). Lembar kerja siswa ini penting agar pada saat siswa melakukan pembelajaran di luar kelas sudah ada panduan yang jelas apa saja yang harus dilakukan. Berdasarkan pengamatan penulis, di lingkungan sekolah masih banyak limbah yang belum diolah, dan kebanyakan limbah yang ada jenisnya adalah anorganik. Jenis penelitian ini merupakan kuasi eksperimen, dengan metode penelitian weak experimental designs, dan desain penelitian the one group pretest-posttes design. Populasi penelitian ini adalah seluruh siswa kelas XI di SMK Negeri 3 Cimahi. Sampel dalam penelitian ini dipilih secara purposive sampling, yakni diambil satu kelas eksperimen, yaitu kelas XI Tata Busana 1. Instrumen yang digunakan berupa LKS yang disusun dengan mengacu pada indikator berpikir kreatif, dan produk kreatif berupa trash fashion. Penilaian produk berdasarkan rubrik yang disusun oleh guru menunjukkan bahwa produk kreatif di atas kriteria ketuntasan minimal (KKM) yang ditetapkan, yakni rata-rata 81 dari rata-rata 73. Pembuatan trash fashion ini merupakan salah satu bukti nyata kepedulian siswa terhadap lingkungan, melatih kreativitas siswa, dan meningkatkan ketrampilan siswa dalam pengolahan limbah menjadi sebuah karya yang bernilai seni dan ekonomis, sehingga dapat membuka peluang usaha.
\end{abstract}

Keywords: PjBL, pembelajaran di luar kelas, trash fashion, kreativitas

\section{LATAR BELAKANG}

Pendidikan memiliki peran strategis dalam meningkatkan kualitas sumber daya manusia dan upaya mewujudkan citacita bangsa Indonesia dalam mewujudkan kesejahteraan umum dan mencerdaskan kehidupan bangsa. Peran strategis inilah yang kemudian mengarahkan pendidikan pada fungsinya dalam mengembangkan kemampuan dan membentuk watak serta peradaban bangsa yang bermartabat dalam rangka mencerdaskan kehidupan bangsa. Terkait dengan hal tersebut, di Indonesia pendidikan nasional bertujuan untuk pengembangan potensi peserta didik agar menjadi manusia yang beriman dan bertakwa kepada Tuhan Yang Maha Esa, berakhlak mulia, sehat, berilmu, cakap, kreatif, mandiri, dan menjadi warga negara yang demokratis serta bertanggung jawab (Syamsudduha, 2012).

Project Based Learning (PjBL) merupakan model pembelajaran yang memberikan kesempatan kepada guru untuk mengelola pembelajaran di kelas dengan melibatkan kerja proyek. Proyek ini memuat tugas yang kompleks berdasarkan pada pertanyaan dan permasalahan yang sangat menantang, dan menuntut siswa bekerja melalui serangkaian tahap metode ilmiah (Thomas dalam Wena 2010). PjBL mengharuskan siswa untuk berpikir kritis, analitis, menggunakan kemampuan berpikir yang tinggi, membutuhkan kolaborasi, komunikasi, pemecahan masalah dan pembelajaran yang mandiri.
Mata Pelajaran IPA merupakan wahana untuk meningkatkan pengetahuan, keterampilan, sikap, dan nilai serta tanggung jawab sebagai seorang warga negara yang bertanggung jawab kepada lingkungan, masyarakat, bangsa, dan negara yang beriman dan bertaqwa kepada Tuhan Yang Maha Esa. IPA berkaitan dengan cara mencari tahu dan memahami tentang alam secara sitematis, sehingga pembelajaran IPA bukan semata hanya untuk penguasaan kumpulan pengetahuan yang berupa faktafakta, konsep-konsep, prinsip-prinsip saja, tetapi juga merupakan suatu proses penemuan. Pendidikan IPA diharapkan dapat menjadi wahana bagi siswa untuk mempelajari dirinya sendiri dan alam sekitarnya.

Penerapan langkah-langkah PjBL dalam memecahkan masalah lingkungan yang terkait dengan pencemaran lingkungan disebut tindakan kreatif. Kondisi yang memungkinkan seseorang menciptakan produk kreatif yang bermakna adalah kondisi pribadi dan lingkungan yaitu sejauh mana keduanya mendorong seseorang untuk melibatkan dirinya dalam proses (kesibukan, kegiatan) kreatif. Guru harus menghargai produk kreativitas siswa dan mengkomunikasikannya kepada yang lain, misalnya dengan mempertunjukkan atau memamerkan hasil karya siswa. Ini akan lebih menggugah minat siswa untuk berkreasi. Orang kreatif biasanya tidak banyak bicara dalam hal bertindak. Apa yang menjadi keyakinannya akan segera dilakukan. Konsep kreatif yang dimiliki akan segera 
ditindak lanjuti menjadi sebuah karya nyata. Karya nyata tersebut berupa produk kreatif yang akan dibuat. Produk adalah hasil dari kualitas unik individu dalam interaksi dengan lingkungannya (Munandar, 2009). Produk kreatif adalah produk harus baru dan nyata. Produk kreatif yang diobservasi meliputi tiga aspek yang ditinjau yaitu dari aspek kognitif, afektif dan psikomotor. Untuk menilai produk kreatif dibuat rubrik yang meliputi keaslian (originalitas), nilai ekonomis, ketepatan waktu dalam mengumpulkan tugas, kebergunaan untuk lingkungan, dan tingkat kesulitan.

Penanganan limbah menjadi kerajinan sudah sering dan banyak dilakukan, namun limbah yang diolah menjadi trash fashion masih jarang dilakukan. Jadi tujuan dari pembuatan trash fashion ini adalah untuk ikut serta melestarikan lingkungan dan sekaligus memperoleh keterampilan dan meningkatkan kreativitas siswa dalam membuat busana dari bahan selain kain, yaitu bahan dari limbah yang ada di lingkungan sekolah dan sekitarnya.

Berdasarkan uraian di atas, maka penelitian ini dilakukan dengan tujuan untuk meningkatkan keterampilan berpikir kreatif sehingga produk penanganan limbah yang dibuat siswa bisa dijadikan busana kreasi yang mempunyai nilai seni yaitu trash fashion. Diharapkan dengan pembuatan produk trash fashion ini akan menambah wawasan tentang pembuatan busana kreasi baru yang dapat membuka cakrawala pandangan dan mengembangkan pengertian tentang busana kreasi baru yang tepat dikalangan masyarakat sekitarnya, membentuk pola pikir yang kreatif dan inovatif berupa ide/gagasan yang melahirkan inspirasi mode busana yang terbuat dari bahan limbah, dan memberikan wawasan dan sumber pengetahuan yang secara tidak langsung dapat memotivasikan dan mendorong pembaca agar lebih tertarik dalam mengembangkan kreativitas dari sampah plastik, serta memberikan informasi dan mengenalkan lebih dekat tentang pemanfaatan sampah plastik yang dapat dimanfaatkan untuk dikreasikan sebagai barang seni.

\section{METODE}

Metode penelitian yang digunakan adalah weak experimental designs atau eksperimen lemah (Fraenkel \& Wallen, 2006). Desain yang digunakan pada penelitian ini adalah the one group pretest-posttest design. Penelitian ini dilakukan di SMK Negeri 3 Cimahi di Provinsi Jawa Barat. Sekolah ini merupakan salah satu sekolah yang sudah berstandar nasional. Populasi yaitu siswa kelas XI bidang keahlian Tata Boga, Tata Busana dan Akomodasi Perhotelan. Kelas XI semuanya berjumlah sepuluh (10) kelas, diambil sampel sebanyak satu (1) kelas. Pemilihan sampel dilakukan dengan cara purposive random sampling, yaitu dipilih salah satu kelas jurusan Tata Busana. Instrumen yang digunakan adalah soal keterampilan berpikir kreatif yang mengacu pada lima indikator berpikir kreatif, yaitu berpikir lancar, berpikir luwes, berpikir orisinal, berpikir memperinci, dan berpikir menilai.pembelajaran yang digunakan dengan menggunakan model pembelajaran berbasis proyek (PjBL). Penilaian produk kreatif dengan menggunakan rubrik yang disusun dengan kriteria yang sudah ditentukan meliputi keaslian produk, tingkat kesulitan, nilai seni, dayaguna produk dan ketepatan dalam mengumpulkan tugas. Datadata yang diperoleh dari hasil instrumen penelitian diolah dan dianalisis. Data kuantitatif dianalisis dengan menggunakan statistik, sedangkan data kualitatif dianalisis secara deskriptif. Pada tahap persiapan, peneliti melakukan observasi lingkungan, menyusun instrumen, Lembar Kerja Siswa (LKS), dan menyusun RPP. Sedangkan pada tahap pelaksanaan, peneliti membagi kelompok, membagikan LKS, membimbing siswa dalam observasi lingkungan, penyusunan rancangan proyek, dan memonitor pembuatan proyek.

\section{HASIL DAN PEMBAHASAN}

Pada penelitian ini dihasilkan beberapa sub pokok bahasan, yaitu keterampilan berpikir kreatif, dan produk kreatif trash fashion.

\section{Ketrampilan Berpikir Kreatif}

Instrumen untuk mengukur keterampilan berpikir kreatif menggunakan 10 soal esay yang mengacu pada indikator lima indikator berpikir kreatif, yaitu berpikir lancar (fluency), berpikir luwes (flexibility), berpikir orisinal (originality), berpikir memperinci (elaboration), dan berpikir menilai (evaluation). Hasil tes keterampilan berpikir kreatif dapat dilihat pada tabel 1 sebagai berikut :

Tabel 1. Deskripsi Keterampilan Berpikir Kreatif

\begin{tabular}{|c|c|c|c|c|c|}
\hline Variabel & $\begin{array}{c}\text { Perla- } \\
\text { kuan }\end{array}$ & $\begin{array}{c}\text { Rata- } \\
\text { rata }\end{array}$ & $\begin{array}{c}\text { Std. } \\
\text { Deviasi }\end{array}$ & $\begin{array}{l}\text { Mak- } \\
\text { simum }\end{array}$ & $\begin{array}{c}\text { Minim } \\
\text { um }\end{array}$ \\
\hline \multirow{3}{*}{$\begin{array}{l}\text { Keteramp } \\
\text { ilan } \\
\text { berpikir } \\
\text { kreatif }\end{array}$} & Pretest & 39,91 & 4,10 & 48,00 & 33,33 \\
\hline & Posttest & 76,53 & 3,39 & 84,00 & 72,00 \\
\hline & N-Gain & 0,61 & 0,04 & 0,70 & 0,53 \\
\hline \multirow{3}{*}{$\begin{array}{l}\text { Berpikir } \\
\text { lancar } \\
\text { (fluency) }\end{array}$} & Pretest & 53,00 & 5,66 & 60,00 & 40,00 \\
\hline & Posttest & 74,33 & 4,50 & 80,00 & 60,00 \\
\hline & N-Gain & 0,46 & 0,05 & 0,56 & 0,33 \\
\hline \multirow{3}{*}{$\begin{array}{l}\text { Berpikir } \\
\text { luwes } \\
\text { (flexibilit } \\
\text { y) }\end{array}$} & Pretest & 58,33 & 6,99 & 70,00 & 40,00 \\
\hline & Posttest & 81,33 & 5,07 & 90,00 & 70,00 \\
\hline & N-Gain & 0,56 & 0,09 & 0,75 & 0,40 \\
\hline \multirow{3}{*}{$\begin{array}{l}\text { Berpikir } \\
\text { orisinal } \\
\text { (originali } \\
\text { ty) }\end{array}$} & Pretest & 57,33 & 10,15 & 80,00 & 40,00 \\
\hline & Posttest & 81,33 & 5,07 & 100,00 & 80,00 \\
\hline & N-Gain & 0,57 & 0,14 & 1,00 & 0,50 \\
\hline \multirow{3}{*}{$\begin{array}{l}\text { Berpikir } \\
\text { memperi } \\
\text { nci } \\
\text { (elaborati } \\
\text { on) }\end{array}$} & Pretest & 0,00 & 0,00 & 0,00 & 0,00 \\
\hline & Posttest & 75,17 & 3,34 & 85,00 & 70,00 \\
\hline & N-Gain & 0,75 & 0,03 & 0,85 & 0,70 \\
\hline \multirow{3}{*}{$\begin{array}{l}\text { Berpikir } \\
\text { menilai } \\
\text { (evaluati } \\
\text { on) }\end{array}$} & Pretest & 53,17 & 7,13 & 70,00 & 40,00 \\
\hline & Posttest & 76,50 & 5,89 & 90,00 & 65,00 \\
\hline & N-Gain & 0,50 & 0,09 & 0,67 & 0,25 \\
\hline
\end{tabular}


Setelah implementasi pembelajaran di luar kelas berbasis proyek keterampilan berpikir kreatif menunjukkan peningkatan karena guru merancang suatu proses pembelajaran yang dimulai dari masalah konstekstual. Siswa mengobservasi lingkungan sekolah, mengidentifikasi jenis-jenis limbah yang ada, menganalisis penyebab permasalahan yang ada di lingkungan, memprediksi jika tidak ada penanganan limbah, dan mencari solusi untuk mengatasi permasalahan tersebut. Siswa diajak untuk berpikir tentang keseharian mereka. Menurut Trianto (2007) pemberian materi pelajaran dengan konteks keseharian siswa di dalam pembelajaran akan menghasilkan dasar-dasar pengetahuan yang mendalam dimana siswa kaya akan pemahaman masalah dan cara untuk menyelesaikannya.

Bila dilihat dari masing-masing indikator keterampilan berpikir kreatif, peningkatan pada indikator berpikir lancar (fluency), berpikir luwes (flexibility), berpikir orisinal (originality), dan pada indikator berpikir menilai (evaluation) berdasarkan kriteria Hake (1999) peningkatan berada pada kategori sedang. Sedangkan pada indikator berpikir memperinci ((elaboration) berdasarkan kriteria Hake (1999) peningkatannya berada pada kategori tinggi. Hal tersebut karena pada saat pretest siswa masih belum mempunyai gambaran proyek yang akan dibuat, sehingga belum bisa membuat rancangan proyek secara rinci. Namun setelah implementasi pembelajaran di luar kelas berbasis proyek, siswa dapat membuat rancangan proyek secara rinci, mulai dari judul proyek, latar belakang, alat dan bahan, cara kerja, kelebihan dan kekuranganya, serta segala hal yang berkaitan dengan proyek yang akan dibuatnya. Sehingga pada saat postest hasil penilaian indikator berpikir memperinci (elaboration) mengalami peningkatan dengan kategori tinggi.

Selanjutnya, rata-rata kreativitas siswa dalam membuat proyek pada aspek tindakan kreatif menunjukkan lebih baik dari nilai kriteria ketuntasan minimal (KKM) yang diterapkan. Hal ini terlihat dari rata-rata posttest sebesar 79,8817 yang lebih besar dari KKM yang ditetapkan, yaitu 73. Setelah implementasi pembelajaran di luar kelas berbasis proyek, siswa menunjukkan hasil rata-rata kreativitas pada aspek tindakan kreatif yang lebih tinggi dari kriteria ketuntasan minimal (KKM) yang ditetapkan. Hal ini karena guru membimbing dan memberi arahan dalam pembuatan rancangan proyek, mulai dari observasi lingkungan sampai dengan solusi untuk mengatasi permasalahan yang ada di lingkungan sekolah, kemudian membuat rancangan proyek secara rinci, dan mempresentasikan rancangan proyek tersebut di depan kelas.

Setiap individu dalam kelompok diobservasi dalam pelaksanaan presentasi yang meliputi: 1) penjelasan identifikasi masalah kelompok, 2) mengkomunikasikan sumber masalah dan memprediksi dampak jika tidak segera diatasi, 3) penjelasan contoh beberapa pemecahan masalah oleh pemerintah, 4) terampil memamerkan gagasan, 5) merinci secara detail, merancang langkah-langkah tindakan yang dilakukan, 6) kelancaran dalam menjawab/merespon pertanyaan/sanggahan/pendapat teman dari kelompok lain, 7) bekerja sama dalam kelompok.

\section{Produk Kreatif Trash Fashion}

Hasil proyek pengolahan limbah yang dilakukan siswa dinilai dengan menggunakan rubrik yang sudah dipersiapkan oleh guru. Deskripsi kreativitas siswa dalam membuat produk dapat dilihat pada tabel berikut ini :

Tabeal 2. Deskripsi Kreativitas Siswa Pada Aspek Produk Kreatif

\begin{tabular}{cc}
\hline Deskriftif & Posttest \\
\hline Rata-rata & 81.17 \\
Std. Deviasi & 2.84 \\
Maksimum & 85.00 \\
Minimum & 75.00 \\
\hline
\end{tabular}

Berdasarkan Tabel 2 di atas diperoleh bahwa kreativitas siswa pada aspek produk kreatif pada saat posttest mempunyai rata-rata 81,17 dengan standar deviasi 2,84 dan skor maksimum 85 serta skor minimum 75. Rata-rata kreativitas siswa dalam membuat proyek pada aspek produk kreatif lebih baik dari nilai kriteria ketuntasan minimal (KKM) yang ditetapkan. Hal ini karena dalam penilaian produk kreatif guru menyampaikan rubrik penilaian produk kreatif, meliputi tiga aspek yang ditinjau yaitu dari aspek kognitif, afektif dan psikomotor. Untuk menilai produk kreatif dibuat rubrik yang meliputi keaslian (originalitas), nilai ekonomis, ketepatan waktu dalam mengumpulkan tugas, kebergunaan untuk lingkungan, dan tingkat kesulitan. Dengan disampaikan kriteria rubrik penilaian tersebut, maka siswa dalam membuat proyek penanganan limbah berusaha untuk sebaik mungkin, tidak asal-asalan saja. Guru juga selalu memonitor dalam pembuatan proyek, sehingga proyek bisa selesai sesuai dengan waktu yang ditetapkan.

\section{KESIMPULAN}

Berdasarkan hasil analisis data dan temuan penelitian, maka disimpulkan bahwa pembelajaran di luar kelas berbasis proyek yang telah dikembangkan dapat meningkatkan keterampilan berpikir kreatif siswa dalam membuat proyek untuk menangani limbah yang ada di lingkungan sekolah. Keunggulan pembelajaran di luar kelas berbasis proyek adalah : a) menumbuhkan partisipasi aktif siswa selama proses pembelajaran, b) memungkinkan guru untuk melakukan layanan, inspirator, fasilitator, pendamping, konsultan, pelatih, motivator siswa sampai menghasilkan tindakan kreatif dan membuat proyek, c) dapat mengembangkan penguasaan materi dan kreativitas siswa dalam memecahkan masalah lingkungan, d) meningkatkan kemauan siswa melaksanakan rancangan tindakan kreatif yang telah dibuat kelompoknya, e) melatih siswa dapat bekerja sama dalam kerja kelompok. Sedangkan keterbatasannya adalah pada implementasi 
dibutuhkan waktu yang lebih banyak dan kesediaan guru dalam membimbing siswa.

\section{IMPLIKASI}

Sebagai suatu penelitian yang telah dilakukan di lingkungan pendidikan maka kesimpulan yang ditarik tentu mempunyai implikasi dalam bidang pendidikan dan juga penelitian-penelitian selanjutnya, sehubungan dengan hal tersebut maka implikasinya adalah sebagai berikut : perlu upaya-upaya yang harus dilakukan oleh lembaga dan guru diantaranya sebagai berikut : 1) Perlu suatu gerakan atau tindakan yang terus menerus dan berkesinambungan untuk memupuk dan menumbuhkan kepedulian siswa terhadap lingkungan, 2) Perlu kerjasama antar berbagai pihak, antar guru, antar mata pelajaran, yang mendukung gerakan peduli lingkungan, 3) Pihak sekolah perlu melengkapi sarana dan prasarana yang mendukung kegiatan pembelajaran, terutama yang berkaitan dengan lingkungan, 4) Perlu dikembangkan penelitian lebih lanjut terkait dengan asesmen sikap kreatif dengan berbagai instrumen lain, seperti observasi dan portofolio.

\section{SARAN}

Dari beberapa hasil penelitian yang dicapai dalam penelitian ini, penulis memberikan saran sebagai berikut : 1) Perlu keterlibatan siswa dalam pembelajaran yang menuntut siswa untuk menuangkan gagasan kreatif dan mau melaksanakan tindakan memecahkan masalah lingkungan, memberi kontribusi pencapaian akademik dan kompetensi yang diharapkan, 2) Agar pembelajaran di luar kelas berbasis proyek dapat berhasil secara optimal, diperlukan guru yang selalu kreatif inovatif dalam memaksimalkan potensi siswa, yaitu dengan jalan memberi contoh-contoh nyata dalam membuat proyek yang berkaitan dengan penanganan limbah, 3) PjBL dapat memberi bekal, ketrampilan dan pengalaman yang mewujudkan kreativitas peserta didik dalam memecahkan masalah lingkungan. Bekal ini dapat dimanfaatkan sebagai life skill dan juga membuka peluang kerja bagi dirinya sendiri maupun orang lain, 4) Tahapan-tahapan pembelajaran yang dikembangkan, serta masalah-masalah lingkungan yang menarik perhatian dapat digunakan untuk dasar penentu kebijakan dalam pengembangan kurikulum IPA Terapan di SMK.

\section{DAFTAR PUSTAKA}

Arikunto, S. (2010). Prosedur Penelitian Suatu Pendekatan Praktik. Jakarta: Rineka Cipta.

Budiarti, M.R., Rintayati, P., \& Daryanto, P. (2014). Peningkatan Pemahaman Konsep Sumber Energi Melalui Metode Pembelajaran Outdoor Study. Penelitian Tindakan Kelas. PGSD FKIP Universitas Sebelas Maret. Surakarta.

Budiman, I., Tjiang, P.C., \& Rusdiana, D. (2008). Model Pembelajaran Latihan Inkuiri Untuk Meningkatkan Penguasaan Konsep Energi Rumah Tangga dan Ketrampilan Berpikir kreatif Siswa SMP. Jurnal Penelitian Pendidikan IPA. Vol. II (2). UPI. Bandung.
Capraro, R.M. \& Slough. SW. 2010. Project-Based Learning (An Integrated Science, Technology, Engineering, and Mathemathics Approach). Rotterdam: Sense Publisher.

Dyah, L. (2012). Pembelajaran Menulis Laporan Pengamatan Dengan Pendekatan Proyek Sebagai Upaya Menumbuhkembangkan Nilai-Nilai Karakter: Studi Eksperimen Kuasi terhadap Peserta didik Kelas V pada SDN 3 Cipatat di Kabupaten Bandung Barat Tahun Ajaran 2011/2012 (Tesis, Universitas Pendidikan Indonesia). (online) http://repository.upi. edu/tesisview.php?no_tesis= 1960

Fatmawati, B. \& Rustaman, N. (2011). The ability design project for improvement creative thingking skills through project based Learning. Proceedings 5th Internationan Seminar on Science Education "Strengthening Science Education through Continuing Teacher professional Development" 12 November 2011, Bandung: School of Post Graduate UPI

Ferdianto, A. (2013). Penerapan Metode Outdoor Study Dengan Memanfaatkan Lingkungan Sekolah Sebagai Sumber Belajar Untuk Meningkatkan Minat dan Hasil Belajar IPA Biologi Siswa Kelas VII B SMP Negeri 3 Tempel. Skripsi tidak diterbitkan, Program Studi Pendidikan Biologi. Fakultas Sains dan Teknologi UIN Sunan Kalijaga. Yogyakarta.

Hake, R.R. (1999). Analyzing change/gain scores. (online) Tersedia:http://www.physics.indiana.edu/ sdi/AnalyzingC hange-Gain.pdf.

Husamah. (2013). Pembelajaran Luar Kelas Outdoor Learning. Jakarta: Prestasi Pustaka.

Jamaludin, D. (2015). Pengaruh Project Based Learning Terhadap Berpikir Kritis, Berpikir Kreatif dan Sikap Ilmiah Pada Materi Tumbuhan Biji. Tesis tidak diterbitkan, Program Studi Pendidikan Biologi. SPS. Universitas Pendidian Indonesia. Bandung.

Khanifah, S., Pukan, K.K., \& Sukaesih, S. (2011). Pemanfaatan Lingkungan Sekolah Sebagai Sumber Belajar Untuk Meningkatkan Hasil Belajar Siswa. Journal of Biology Education. Fakultas MIPA. Universitas Negeri Semarang. Semarang.

Kusnadi \& Yanti, K. L. (2011). Implementation of PjBL Model to Improve Student's Learning Outcome and Motivation Of Junior High School on The Diversity of Life Concept. Dalam Proceedings 5th Internationan Seminar on Science Education "Strengthening Science Education through Continuing Teacher professional Development" 12 November 2011, Bandung: School of Post Graduate UPI

Maspupah, M., Koesbandiah, H.S., \& Saefudin. (2007). Efektivitas Pembelajaran Dengan Menggunakan Pembelajaran Nilai Untuk Meningkatkan Hasil Belajar, Sikap, dan Minat Pada Konsep Ekologi. Jurnal Penelitian Pendidikan IPA Vol. 1 (3). UPI. Bandung.

McGregor, D. (2007). Developing Thingking; Developing Learning A Guide to Thinking Skill in Education. Enggland. Mc Graw Hill.

Munandar, U. (2005). Mengembangkan Bakat dan Kreativitas Anak (Petunjuk Orang Tua). Jakarta. Rineka Cipta.

Munandar, U. (2012). Pengembangan Kreativitas Anak Berbakat. Jakarta. Rineka Cipta. 
(1992). Mengembangkan Bakat dan Kreativitas Anak Sekolah. Gramedia: Jakarta

Murbangun, N. (2013). Pengembangan perkuliahan kimia lingkungan berbasis masalah bervisi green chemistry untuk meningkatkan kreatifitas mahasiswa. Disertasi tidak diterbtkan, Sekolah pascasarjana. Universitas Pendidikan Indonesia

Priest, S. (1986). Redefining outdoor education: A matter of many relationships. Journal of Environmental Education, 17(3), $13-15$

Setiasih, A. 2010. Model Pembelajaran Proyek Berbasis Lingkungan Perkembangan Untuk Meningkatkan Keterampilan Pemecahan Masalah: Studi Kuasi Eksperimen pada Anak TK di Kota Cimahi. (Disertasi tidak diterbitkan, Universitas Pendidikan Indonesia). (online) $\mathrm{http} / / /$ repository.upi.edu/disertasiview.php?no_disertasi=21 6

Susanti, (2012). Pengaruh pembelajaran berbasis proyek dan pembelajaran berbasis praktikum terhadap kemampuan berpikir kreatif dan sikap siswa SMA kelas XI pada materi nutrisi. Tesis. Universitas Pendidikan Indonesia. Bandung

Syamsudduha, St. (2012). Penggunaan Lingkungan Sekolah Sebagai Sumber Belajar Dalam Meningkatkan Hasil Belajar Biologi. Lentera Pendidikan. Vol. 15(18). Fakultas Tarbiyah dan Keguruan UIN Alaudin Makasar.

Vera, A. (2012). Metode Mengajar Anak di Luar Kelas (Outdoor Study). Jogjakarta: DIVA Press.

Wena, M. (2010). Strategi Pembelajaran Inovatif Kontemporer (Suatu Tinjauan Konseptual Operasional). Jakarta: Bumi Aksara. 